\title{
Mathematical modelling of surface irrigation for field crops in Jordan based on soil hydrological-physical properties
}

\author{
Mohunnad Massimi \\ Kerpely Kálmán Doctoral School of Horticultural Sciences, \\ Institute of Plant Protection, University of Debrecen \\ mohunnad.massimi@agr.unideb.hu
}

\begin{abstract}
SUMMARY
Jordan suffers from drought and depletion of water resources. In-field crop management, the issue of irrigation scheduling is important and influential. In this research note, a simple method was developed for scheduling surface irrigation of field crops based on inputs of crop ecology, effective root depth, soil texture, soil hydrology, and logical mathematics. It was concluded that the science of mathematics has succeeded to meet academic irrigation scheduling in terms of surface irrigation for field crops based on both soil hydrological and physical traits. Extension scholar has a decision to choose mathematical irrigation model depends on the traditional inputs or updating the model by searching for renewable inputs such as different varieties root depths, optimum row spacing of each crop, drip irrigation mathematical modelling, and digital sensing. In both cases, the input related to the effective root depth is a major and basic factor in mathematical irrigation scheduling. It is, therefore, recommendable that extension research-based systems should focus on basic mathematics to capacitate the complementary role of academics, research, and extension in irrigation modelling, and rural development.
\end{abstract}

Keywords: irrigation schedule; soil management; mathematics modelling; sensors; effective root depth

\section{INTRODUCTION}

Jordan is currently facing climate problems represented by depletion of water resources, high temperatures, drought, salinization of soils, and groundwater sources. Irrigation scheduling and modelling is a scientific and practical concept of determining the amount of irrigation each time and irrigation intervals (Phocaides, 2007). There is a balance between the two parties (irrigation amount, and irrigation intervals) in Jordan's case due to the conditions of drought, salinity, depletion of water resources, and erratic distribution of rain in the various regions. The availability of modern sewage treatment plants and the availability of high-volume treated water is another reason for the need to schedule irrigation, especially in the production of field and forage crops. Irrigation scheduling can be managed preciously to meet crop water demands, holding the promise of increased yield and quality (Kahlon, 2017). There are major basic inputs that must be discussed in irrigation modelling.

First, crop growth stages. Irrigating the crop only at drought-sensitive growth stages can help to manage water resources to meet crop water requirements Du et al. (2010). Rainfed agriculture cannot be relied upon to produce forage crops to compete with imported agricultural products. While scheduling the irrigation of these crops is important to balance the production, marketing, and competition on the one side and the management of the most important agricultural resource in Jordan, irrigation water on the other side. Greaves and Wang (2017) concluded that long drought cycles on corn are attributed to lower rainfall. Similar results emphasized the negative effect of drought on the growth of corn reported Randhawa et al. (2017). Corn is sensitive to moisture stress during vegetative growth and tasselling stages (Anandhi, 2016). Drought stress at these critical growth stages of corn led to reduced growth represented by plant height and leaf area development (Cakir, 2004). Ali et al. (2007) identified the stages of tillering and stem elongation as one of the moisture-sensitive stages in the wheat crop. Limited irrigation water availability can cause an increase in crop failure, defined as the complete loss of crops on a farm (Anandhi and Blocksome, 2017). It can be concluded that green forage crops need irrigation immediately after harvest to confirm re-growth (such as; alfalfa, Egyptian clover, field (silage) corn, forage sorghum, rye-grass, and Sudan-grass). Other crops need irrigation water in the stages of tillering and flowering (barley, oat, triticale, and wheat). Legumes crops are sensitive to irrigation water at flowering stages and pod filling (lentil).

Second, in addition to crop growth stages, soil texture is an important issue in this regard. Each soil texture has different hydrological properties especially about its water retention potential. Thus, soil texture can influence soil water relationships. Once the sand, silt, and clay fractions are known, the textural class can be determined. There are no soil maps in the agricultural areas of Jordan. Easton and Bock (2016) reported the plant available water percentage for several soil texture classes (sand, sandy loam, loam, silt loam, clay loam, silty clay, and clay). It was reported that many soil properties are influenced by texture, including drainage, and water-holding capacity. It can be concluded that the soil texture class has an impact on soil hydrological properties (Easton and Bock, 2016).

Third, effective root depth. The effective root zone is the depth within which most crop roots are concentrated (Alberta Agriculture and Rural Development, 2011). Those are depths to which the roots of mature crops will deplete the available water supply when grown in a deep permeable soil under 
average conditions (Fan et al., 2016). The effective root zone depth is the depth of soil used by the main body of the plant roots to obtain most of the stored moisture under proper irrigation. Each plant has its root development characteristics. The application of irrigation water should be limited to an amount that will penetrate only to the effective root zone depth.

This short research note aims to design or propose a simple mathematical system for irrigation scheduling for field crops that considers logical simplicity and combines academic natural mathematics science, and extension, while highlighting the basic elements in modelling such as effective root depth, soil texture, and crop growth stages.

\section{METHODOLOGY}

The article explains the method used to schedule irrigation of field and forage crops in Jordan using surface irrigation. All the crops under this study are sown based on seed weights within specific seed rates and are not grown in a row, making the idea of irrigating by surface irrigation suitable. This study will cover the field and basic forage crops in Jordan: alfalfa, barley, Egyptian clover, field corn (silage corn), forage sorghum, rye-grass, Sudan-grass, and triticale. The most important field food crops were added: lentils, oat, and wheat. Oat and wheat are also used as forage crops. The study does not include field crops that are grown to take dry grains such as beans, chickpeas, cowpea, fababeans, and peas and does not include sweet corn which can be grown mainly as vegetable horticultural crops in the open field (Massimi et al., 2018a). Lupines (Lupinus spp.), millets (Panicum miliaceum L.), and soybeans [(Glycine $\max (\mathrm{L})$.$) Merr.] are not common$ field crops in Jordan. Therefore, these crops were not addressed in this research.

Food and Agricultural Organization has conducted specialized calculations and water needs assessment trials for crops (Brouwer et al., 1986). The effective root zone is the depth within which most crop roots are concentrated, it is a measure of soil depth that holds the bulk of roots (Table 1). Several references have been used to document the comparison between crops regarding root depth. Table 1 illustrates this.

The effective root zone is the depth within which most crop roots are concentrated, which was estimated as $\sim 120 \mathrm{~cm}$ for alfalfa, and as $\sim 50-100 \mathrm{~cm}$ for barley, and wheat (Alberta Agriculture and Rural Development, 2011). These values were comparable with our estimated values (Table 1), which were used as a measure of soil depth that holds the bulk of roots for alfalfa, barley, Lentil, oat, and wheat (Fan et al., 2016). Depths to which the roots of mature crops will deplete the available water supply when grown in a deep permeable, well-drained soil under average conditions were used for Sudan-grass and field corn (which was estimated also for sorghum as for Sudangrass) (University of California UC Drought Management, 2016). Various other references have been used to determine the depth of the roots of the Egyptian clover (Sustainable Agriculture Research \& Education SARE, 2012), rye-grass (Steynberg et al., 1994), and triticale (Bonachela, 1996) crops.

Table 1. Major and most common field crops grown in Jordan and their morphological and ecological traits

\begin{tabular}{|c|c|c|c|c|c|}
\hline No. & Crop & Scientific Name & $\begin{array}{c}\text { Annual, or } \\
\text { Perennial } \\
\text { Crop }\end{array}$ & $\begin{array}{l}\text { Summer, or } \\
\text { Winter Crop }\end{array}$ & $\begin{array}{l}\text { Root Depth } \\
\text { (cm) }\end{array}$ \\
\hline 1 & Alfalfa & Medicago sativa $\mathrm{L}$. & $\mathrm{P}$ & - & 135.6 \\
\hline 2 & Barley & Hordeum vulgare L. & A & W & 99.6 \\
\hline 3 & Egyptian Clover & Trifolium alexandrinum $\mathrm{L}$. & A & W & 17.78 \\
\hline 4 & $\begin{array}{l}\text { Field } \\
(\text { Silage } \dagger) \text { Corn }\end{array}$ & Zea mays var. indentata L. & A & $\mathrm{S}$ & 91.44 \\
\hline 5 & Forage Sorghum & Sorghum bicolor L. & A & $\mathrm{S}$ & 106.68 \\
\hline 6 & Lentil $!$ & Lens esculenta Moench. & A & $\mathrm{W}$ & 73.7 \\
\hline 7 & Oat + & Avena sativa $\mathrm{L}$ & A & $\mathrm{W}$ & 77.7 \\
\hline 8 & Rye-grass & Lolium multiflorum Lam. & A & $\mathrm{W}$ & 100 \\
\hline 9 & Sudan-grass & Sorghum $\times$ drummondii. & A & $\mathrm{S}$ & 106.68 \\
\hline 10 & Triticale & $\begin{array}{l}\text { X Triticosecale Witt. } \\
\text { Bread: Triticum aestivum } \mathrm{L} .\end{array}$ & A & W & 135 \\
\hline 11 & Wheat $t$ & $\begin{array}{l}\text { Macaroni: Triticum durum or Triticum turgidum } \\
\text { subsp. Durum }\end{array}$ & A & $\mathrm{W}$ & 103.8 \\
\hline
\end{tabular}

A: Shows that the crop is Annual, P: Shows that the crop is Perennial.

W: Winter Crop, S: Summer Crop.

$\dagger$ : Grown for silage (multiple harvests or cuts).

t: Mainly food crops.

-: Shows that the crop is not within this box.

The water requirements of the crops were concluded and estimated daily by dividing the maximum water requirements for each crop during the growing season by the maximum total number of days 
of each crop season (Table 2). Seasonal water requirement information is documented by reference (Brouwer and Heibloem, 1986). Other sources were used for the following crops: Egyptian clover (Reed, 2008), lentil (Saraf and Baitha, 1985), rye-grass (Dickinson et al., 2004), and triticale (Info agro, 2018).
On the other hand, the total growing period $(* *)$ in days is cited in (Brouwer and Heibloem, 1986), (+) cited in (Kroeck, 2011). The total growing period in days cited in both references was written in $(++)$. The total growing period in days for is triticale is estimated like similar crops (Barley and Wheat) (***).

Table 2. Seasonal water requirement (mm), total growing period (days), and daily water requirement (mm/day) for major and most common field crops grown in Jordan

\begin{tabular}{|c|c|c|c|c|}
\hline No. & Crop & $\begin{array}{c}\text { Seasonal Water } \\
\text { Requirement }(\mathrm{mm})\end{array}$ & $\begin{array}{c}\text { Total Growing Period } \\
\text { (Days) }\end{array}$ & $\begin{array}{c}\text { Daily Water Requirement } \\
(\mathrm{mm} / \mathrm{Day})\end{array}$ \\
\hline 1 & Alfalfa & $800-1600$ & $(100-365)^{* *}$ & 4.3 \\
\hline 2 & Barley & $450-650$ & $(90)^{+}-(120)^{++}-(150)^{* *}$ & 4.3 \\
\hline 3 & $\begin{array}{l}\text { Egyptian } \\
\text { Clover }\end{array}$ & $(>600)^{*}$ & $(90-120)^{+}$ & 5 \\
\hline 4 & $\begin{array}{l}\text { Field (Silage) } \\
\text { Corn }\end{array}$ & $500-800$ & $(90)^{+}$ & 8.9 \\
\hline 5 & Forage Sorghum & $450-650$ & $(90)^{+}-(120)^{++}-(130)^{* *}$ & 5 \\
\hline 6 & Lentil & $(230-912)^{*}$ & $(150-170)^{* *}$ & 5.3 \\
\hline 7 & Oat & $450-650$ & $(60-90)^{+}-(120)^{++}-(150)^{* *}$ & 4.3 \\
\hline 8 & Rye-grass & $(1200)^{*}$ & $(60-90-120)^{+}$ & 10 \\
\hline 9 & Sudan-grass & $450-650$ & $(90-120)^{+}$ & 5.4 \\
\hline 10 & Triticale & $(400-900)^{*}$ & $(90-120-150)^{* * *}$ & 6 \\
\hline 11 & Wheat & $450-650$ & $(120-150)^{* *}$ & 4.3 \\
\hline
\end{tabular}

*: Seasonal Water Requirements: scientific sources other than (Brouwer and Heibloem, 1986).

**: Total Growing Period (days) cited in (Brouwer and Heibloem, 1986).

***: Total Growing Period (days) for triticale.

+: Total Growing Period (days) cited in (Kroeck, 2011).

++: Total Growing Period (days) cited in both references: (Brouwer and Heibloem, 1986), and (Kroeck, 2011).

\section{Scientific and Practical Approach (Using Digital Sensors)}

1. A representative sample of the soil is taken, send to the laboratory to determine the soil texture and soil bulk density.

2. Check the laboratory results by adding a quantity of water to another soil sample for saturation. Saturation is the soil water content when all pores are filled with water. Field capacity is the soil water content after the soil has been saturated and allowed to drain freely for about 24 to 48 hours. Free drainage occurs because of the force of gravity pulling on the water, record the soil moisture content $\%$ by using an electronic digital probe (by weight) used in Figure 1. Relative humidity informs how much water vapor is in the air compared with the maximum possible. At its maximum, denoted as saturation, the relative humidity is $100 \%$, and evaporation is inhibited, The use of a Hygro-Thermometer probe at the time of soil drainage is important because controlling $100 \%$ relative humidity will stop evaporation from the soil and ensure gravity discharge (Figure 2).

3. By reference to Table 3 where the soil moisture content $\%$ multiplied by the soil bulk density ( $g$ $\mathrm{cm}^{-3}$ ) to determine the field capacity \% (by volume) from Table 3 .

FC \% (v\%) = S.M.C \% (Wt \%) (S.B.D $\left(\mathrm{g} \mathrm{cm}^{-3}\right) /$ Water Density $\left(\mathrm{g} \mathrm{cm}^{-3}\right)$. Water Density equals 1 $\mathrm{g} \mathrm{cm}^{-3}$.

FC $\%(\mathrm{v} \%)=$ Field Capacity Percentage (Volume Percentage), S.M.C $\%=$ Soil Moisture Content Percentage (Weight Percentage $)=$ Weight of Water $(\mathrm{g}) /$ Weight of Dry Soil (g), S.B.D=Soil Bulk Density = Weight of Dry Soil $(\mathrm{g}) /$ Soil Volume $\left(\mathrm{cm}^{3}\right)$.

4. Steps can be shortened by starting the second step directly and relying on algebraic calculations through the inputs documented in Tables 2 and 3 to schedule irrigation. Soil access to a saturation level can be achieved after rain or irrigation. 
Table 3. The ideal bulk density $\left(\mathrm{g} \mathrm{cm}^{-3}\right)$ of each soil texture, indicating the field capacity percentage and permanent welting point percentage

\begin{tabular}{|c|c|c|c|c|}
\hline No. & Soil Texture & $\begin{array}{c}\text { Ideal Bulk Density for Plant } \\
\text { Growth }\left(\mathrm{g} \mathrm{cm}^{-3}\right) \dagger \dagger\end{array}$ & $\begin{array}{c}\text { Field Capacity }(\mathrm{v} \%) \\
+t\end{array}$ & $\begin{array}{c}\text { Permanent Wilting Point (v\%) } \\
\text { tf }\end{array}$ \\
\hline 1 & Sand & 1.6 & 10 & 5 \\
\hline 2 & Loamy Sand & 1.6 & 12 & 5 \\
\hline 3 & Sandy Loam & 1.4 & 18 & 8 \\
\hline 4 & Loam & 1.4 & 28 & 14 \\
\hline 5 & Sandy Clay Loam & 1.4 & 27 & 17 \\
\hline 6 & Clay Loam & $1.4+$ & 36 & 22 \\
\hline 7 & Silt & 1.4 & 30 & 6 \\
\hline 8 & Silt Loam & 1.4 & 31 & 11 \\
\hline 9 & Silty Clay Loam & 1.4 & 38 & 22 \\
\hline 10 & Sandy Clay & 1.1 & 36 & 25 \\
\hline 11 & Silty Clay & 1.1 & 41 & 27 \\
\hline 12 & Clay Loam & $1.1+$ & 36 & 22 \\
\hline 13 & Clay & 1.1 & 42 & 30 \\
\hline
\end{tabular}

$\uparrow \dagger$ Maximum Values Taken from Soil Health- Guides for Educators (NRCS, 2014). A laboratory test may result in a different value.

tt Taken from (Saxton et al., 2006).

+: The reference Soil Health- Guides for Educators (NRCS, 2014) have two values for this texture

Basic Mathematical Modelling Approach (Table 4):

1. The mathematical schedule for surface irrigation will be used rather than drip irrigation, meaning that the cultivation of these crops will be linked to a specific seed rate for the unit area without the need for seed drilling.

2. Managed Allowable Depletion (MAD \%) is the percentage of water available that taken by the plant. The calculations will be based on the assumption that the value is $30 \%$ as a constant indicator value of preparation for the next irrigation event.

3. It is assumed that surface irrigation efficiency is only $60 \%$ (runoff and deep percolation are substantial, but evaporation losses are generally small).

4. $\mathrm{NIR}=(\mathrm{MAD} \% \times(\mathrm{FC} \%-\mathrm{PWP} \%) \times \mathrm{D}(\mathrm{cm}) \times$ 10). The result is multiplied with 10 to convert the value to $\mathrm{mm}$. GIR $=$ NIR $/$ E \% .

Intervals (Days) $=$ WDS (NIR) / DWR (mm). NIR: Net Irrigation Requirement, GIR: Gross Irrigation Requirement, FC \%: Field Capacity Percentage (Volume Percentage), PWP \%: Permanent Wilting Point Percentage, D: Root Depth, E\%: Irrigation Efficiency, WDS: Water Depth in Soil, and DWR: Daily Water Requirement.

5. Use a rain gauge to subtract rain amounts from gross irrigation requirements, the net irrigation requirements are re-calculated based on the adjusted gross irrigation requirements (Figure 3).

6. All the numbers in Table 4 are averages based on weather conditions, especially temperatures, soil texture, and stages of growth.

7. All math scores were rounded to the nearest integer number based on the mathematical rules: look at the digits in the tenth's place and avoid double-round.

7.1 Specific Conversion Notes: The records of Gross Irrigation Requirement (GIR) and Net Irrigation Requirement (NIR) will be in millimeters per square meter, i.e., one meter per 0.1 hectares. Every 1000 millimeters is equal to 1 meter (distance or depth of irrigation in one dimension and not a volumetric value) and every 1000 square meters equals 1 dunum (0.1 hectares). Thus, $1000 \mathrm{~mm} / 1000 \mathrm{~m}^{2}=1$ meter/ 0.1 hectares.

7.2 The rounded mean and mode were calculated for all types of soil textures in each crop for parameters of gross, net irrigation requirements, and irrigation intervals, as well as statistical correlation, was extracted between root depths $(\mathrm{cm})$, gross irrigation requirements mean $\left(\mathrm{m}^{3}\right)$, and irrigation intervals mean (days) for each crop following the analysis by (Carlberg, 2014).

Figure 1. Electronic probe for soil moisture content (model MO750)

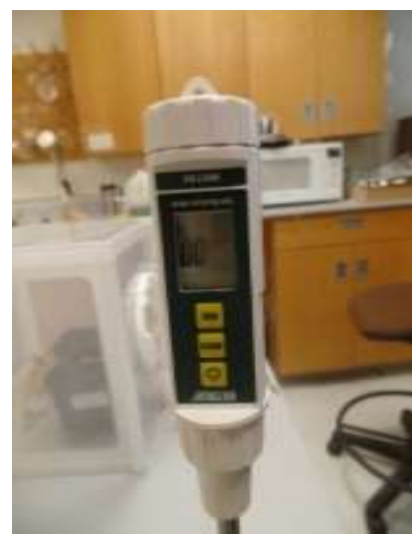


Figure 2. Hygro-Thermometer

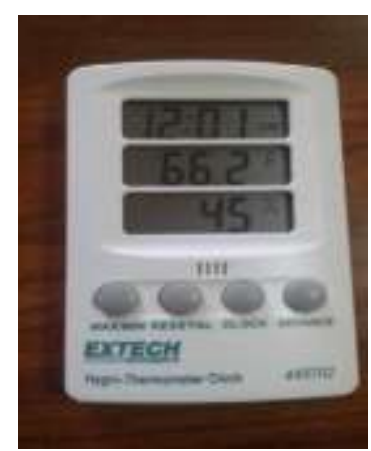

(model 445702) sensor for relative humidity (10-85\%) percentage sensor $\left(1^{\circ} \mathrm{F}=-17.22^{\circ} \mathrm{C}\right)$.

Figure 3. Measure the amount of rain using rainfall gauge

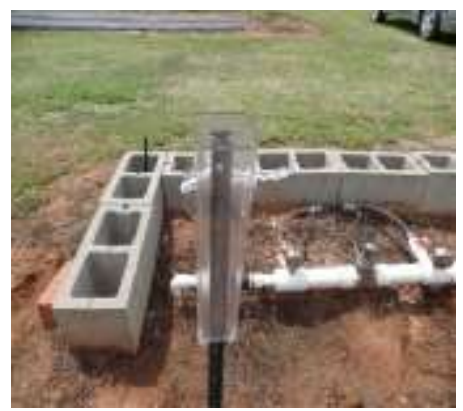

$(1 \mathrm{inch}=2.54 \mathrm{~cm}, 1 \mathrm{~cm}=10 \mathrm{~mm})$

7.3 It is necessary to determine the quantities of rain when winter crops are planted to be subtracted from the quantities approved in the mathematical schedule.

\section{RESULTS AND DISCUSSION}

The calculations in the Table 4 (A to $\mathrm{K}$ ) show that the mathematical approach gives a theoretical indication of how each crop is treated for irrigation in its both dimensions; amount (quantity) and irrigation intervals. All the numbers in the Table 4 (A to K) are means based on weather conditions, especially temperatures, and based on stages of growth, and soil texture class (minimum to maximum).

This study shows the average gross and net irrigation requirements proposed mathematically for each crop in addition to the average time of days between each irrigation and the other (by devising the average for 13 soil texture classes).

From the results of the calculations, the calculated numbers of the soil texture sandy loam appear to be similar to the soil texture sandy clay loam. Similar findings were recorded for loam, clay loam, and silty clay (mode). It is also noted that the highest readings were for the three soil textures (silt, silt loam, and silty clay loam, respectively) for all crops. While the lowest was recorded for sand soils (Table 4: A to K).

The high percentage of available water in the three soil texture classes (silt $24 \%$, silt loam $20 \%$, and silty clay loam $16 \%$, respectively) is what led to an increase in the parameters records related to the irrigation quantities and irrigation intervals compared to sand (5\%) and loamy sand (7\%). Easton and Bock (2016) reported that sand texture had the lowest average available water (7\%) in comparison to loam (20\%) and silt loam (21\%) and comparison to several other soil textures. However, crops cannot be classified according to the optimum soil texture because there are important chemical factors that must be studied such as soil acidity ( $\mathrm{pH})$, electrical conductivity i.e.; salinity (EC), and total dissolved salts (TDS) before any generalization.

Table 4. Statement of the result of mathematical calculations of the gross (GIR $\left.\left(\mathbf{m}^{3} / 0.1 \mathrm{ha}\right)\right)$ and net $\left(\mathrm{NIR}\left(\mathrm{m}^{3} / \mathbf{0 . 1 h a}\right)\right)$ irrigation requirements of each crop (A-K) and their irrigation intervals (days)

\begin{tabular}{|c|c|c|c|}
\hline \multicolumn{4}{|c|}{ (A) Alfalfa } \\
\hline Soil Texture & $\begin{array}{c}\text { Gross Irrigation } \\
\text { Requirement }\end{array}$ & $\begin{array}{c}\text { Net Irrigation } \\
\text { Requirement }\end{array}$ & $\begin{array}{c}\text { Intervals } \\
\text { (Days) }\end{array}$ \\
\hline Sand & 34 & 20 & 5 \\
\hline Loamy Sand & 47 & 28 & 7 \\
\hline Sandy Loam & 68 & 41 & 9 \\
\hline Loam & 95 & 57 & 13 \\
\hline Sandy Clay Loam & 68 & 41 & 9 \\
\hline Clay Loam & 95 & 57 & 13 \\
\hline Silt & 163 & 98 & 23 \\
\hline Silt Loam & 136 & 81 & 19 \\
\hline Silt Clay Loam & 108 & 65 & 15 \\
\hline Sandy Clay & 75 & 45 & 10 \\
\hline Silty Clay & 95 & 57 & 13 \\
\hline Clay & 81 & 49 & 11 \\
\hline Clay Loam & 95 & 57 & 13 \\
\hline Mode & 95 & 57 & 13 \\
\hline Min-Max & $34-163 \mathrm{~m}^{3}$ & $20-98 \mathrm{~m}^{3}$ & 5-23 days \\
\hline Mean & $89 \mathrm{~m}^{3}$ & $54 \mathrm{~m}^{3}$ & 12 \\
\hline
\end{tabular}


Table 4 continued (B) Barley

\begin{tabular}{|c|c|c|c|}
\hline Soil Texture & $\begin{array}{c}\text { Gross Irrigation } \\
\text { Requirement }\end{array}$ & $\begin{array}{c}\text { Net Irrigation } \\
\text { Requirement }\end{array}$ & $\begin{array}{c}\text { Intervals } \\
\text { (Days) }\end{array}$ \\
\hline Sand & 25 & 15 & 3 \\
\hline Loamy Sand & 35 & 21 & 5 \\
\hline Sandy Loam & 50 & 30 & 7 \\
\hline Loam & 70 & 42 & 10 \\
\hline Sandy Clay Loam & 50 & 30 & 7 \\
\hline Clay Loam & 70 & 42 & 10 \\
\hline Silt & 120 & 72 & 17 \\
\hline Silt Loam & 100 & 60 & 14 \\
\hline Silt Clay Loam & 80 & 48 & 11 \\
\hline Sandy Clay & 55 & 33 & 8 \\
\hline Silty Clay & 70 & 42 & 10 \\
\hline Clay & 60 & 36 & 8 \\
\hline Clay Loam & 70 & 42 & 10 \\
\hline Mode & 70 & 42 & 10 \\
\hline Min-Max & $25-120 \mathrm{~m}^{3}$ & $15-72 \mathrm{~m}^{3}$ & 3-17 days \\
\hline Mean & $66 \mathrm{~m}^{3}$ & $\mathbf{m}^{3}$ & 9 \\
\hline
\end{tabular}

(C) Egyptian Clover

\begin{tabular}{|c|c|c|c|}
\hline Soil Texture & $\begin{array}{c}\text { Gross Irrigation } \\
\text { Requirement }\end{array}$ & $\begin{array}{l}\text { Net Irrigation } \\
\text { Requirement }\end{array}$ & $\begin{array}{c}\text { Intervals } \\
\text { (Days) }\end{array}$ \\
\hline Sand & 4 & 3 & 1 \\
\hline Loamy Sand & 6 & 4 & 1 \\
\hline Sandy Loam & 9 & 5 & 1 \\
\hline Loam & 12 & 7 & 1 \\
\hline Sandy Clay Loam & 9 & 5 & 1 \\
\hline Clay Loam & 12 & 7 & 1 \\
\hline Silt & 21 & 13 & 3 \\
\hline Silt Loam & 18 & 11 & 2 \\
\hline Silt Clay Loam & 14 & 9 & 2 \\
\hline Sandy Clay & 10 & 6 & 1 \\
\hline Silty Clay & 12 & 7 & 1 \\
\hline Clay & 11 & 6 & 1 \\
\hline Clay Loam & 12 & 7 & 1 \\
\hline Mode & 12 & 7 & 1 \\
\hline Min-Max & $4-21 \mathrm{~m}^{3}$ & $3-13 \mathrm{~m}^{3}$ & 1-3 days \\
\hline Mean & $12 \mathrm{~m}^{3}$ & $7 \mathrm{~m}^{3}$ & 1 \\
\hline \multicolumn{4}{|c|}{ (D) Field (Silage) Corn } \\
\hline Soil Texture & $\begin{array}{c}\text { Gross Irrigation } \\
\text { Requirement }\end{array}$ & $\begin{array}{c}\text { Net Irrigation } \\
\text { Requirement }\end{array}$ & $\begin{array}{c}\text { Intervals } \\
\text { (Days) }\end{array}$ \\
\hline Sand & 23 & 14 & 2 \\
\hline Loamy Sand & 32 & 19 & 2 \\
\hline Sandy Loam & 46 & 27 & 3 \\
\hline Loam & 64 & 38 & 4 \\
\hline Sandy Clay Loam & 46 & 27 & 3 \\
\hline Clay Loam & 64 & 38 & 4 \\
\hline Silt & 110 & 66 & 7 \\
\hline Silt Loam & 91 & 55 & 6 \\
\hline Silt Clay Loam & 73 & 44 & 5 \\
\hline Sandy Clay & 50 & 30 & 3 \\
\hline Silty Clay & 64 & 38 & 4 \\
\hline Clay & 55 & 33 & 4 \\
\hline Clay Loam & 64 & 38 & 4 \\
\hline Mode & 64 & 38 & 4 \\
\hline Min-Max & $23-110 \mathrm{~m}^{3}$ & $14-66 \mathrm{~m}^{3}$ & 2-7 days \\
\hline Mean & $60 \mathrm{~m}^{3}$ & $36 \mathrm{~m}^{3}$ & 4 \\
\hline
\end{tabular}


DOI: 10.34101/ACTAAGRAR/1/8341

Table 4 continued

(E) Forage Sorghum

\begin{tabular}{|c|c|c|c|}
\hline Soil Texture & $\begin{array}{c}\text { Gross Irrigation } \\
\text { Requirement }\end{array}$ & $\begin{array}{c}\text { Net Irrigation } \\
\text { Requirement }\end{array}$ & $\begin{array}{c}\text { Intervals } \\
\text { (Days) }\end{array}$ \\
\hline Sand & 27 & 16 & 3 \\
\hline Loamy Sand & 37 & 22 & 4 \\
\hline Sandy Loam & 53 & 32 & 6 \\
\hline Loam & 75 & 45 & 9 \\
\hline Sandy Clay Loam & 53 & 32 & 6 \\
\hline Clay Loam & 75 & 45 & 9 \\
\hline Silt & 128 & 77 & 15 \\
\hline Silt Loam & 107 & 64 & 13 \\
\hline Silt Clay Loam & 85 & 51 & 10 \\
\hline Sandy Clay & 59 & 35 & 7 \\
\hline Silty Clay & 75 & 45 & 9 \\
\hline Clay & 64 & 38 & 8 \\
\hline Clay Loam & 75 & 45 & 9 \\
\hline Mode & 75 & 45 & 9 \\
\hline Min-Max & $27-128 \mathrm{~m}^{3}$ & $16-77 \mathrm{~m}^{3}$ & 3-15 days \\
\hline Mean & $70 \mathrm{~m}^{3}$ & $42 \mathrm{~m}^{3}$ & 8 \\
\hline \multicolumn{4}{|c|}{ (F) Lentil } \\
\hline Soil Texture & $\begin{array}{c}\text { Gross Irrigation } \\
\text { Requirement }\end{array}$ & $\begin{array}{c}\text { Net Irrigation } \\
\text { Requirement }\end{array}$ & $\begin{array}{c}\text { Intervals } \\
\text { (Days) }\end{array}$ \\
\hline Sand & 18 & 11 & 2 \\
\hline Loamy Sand & 26 & 15 & 3 \\
\hline Sandy Loam & 37 & 22 & 4 \\
\hline Loam & 52 & 31 & 6 \\
\hline Sandy Clay Loam & 37 & 22 & 4 \\
\hline Clay Loam & 52 & 31 & 6 \\
\hline Silt & 88 & 53 & 10 \\
\hline Silt Loam & 74 & 44 & 8 \\
\hline Silt Clay Loam & 59 & 35 & 7 \\
\hline Sandy Clay & 41 & 24 & 5 \\
\hline Silty Clay & 52 & 31 & 6 \\
\hline Clay & 44 & 27 & 5 \\
\hline Clay Loam & 52 & 31 & 6 \\
\hline Mode & 52 & 31 & 6 \\
\hline Min-Max & $18-88 \mathrm{~m}^{3}$ & $11-53 \mathrm{~m}^{3}$ & 2-10 days \\
\hline Mean & $49 \mathrm{~m}^{3}$ & $29 \mathrm{~m}^{3}$ & 6 \\
\hline
\end{tabular}

(G) Oat

\begin{tabular}{|c|c|c|c|}
\hline Soil Texture & $\begin{array}{c}\text { Gross Irrigation } \\
\text { Requirement }\end{array}$ & $\begin{array}{l}\text { Net Irrigation } \\
\text { Requirement }\end{array}$ & $\begin{array}{c}\text { Intervals } \\
\text { (Days) }\end{array}$ \\
\hline Sand & 19 & 12 & 3 \\
\hline Loamy Sand & 27 & 16 & 4 \\
\hline Sandy Loam & 39 & 23 & 5 \\
\hline Loam & 54 & 33 & 8 \\
\hline Sandy Clay Loam & 39 & 23 & 5 \\
\hline Clay Loam & 54 & 33 & 8 \\
\hline Silt & 93 & 56 & 13 \\
\hline Silt Loam & 78 & 47 & 11 \\
\hline Silt Clay Loam & 62 & 37 & 9 \\
\hline Sandy Clay & 43 & 26 & 6 \\
\hline Silty Clay & 54 & 33 & 8 \\
\hline Clay & 47 & 28 & 7 \\
\hline Clay Loam & 54 & 33 & 8 \\
\hline Mode & 54 & 33 & 8 \\
\hline Min-Max & $19-93 \mathrm{~m}^{3}$ & $12-56 \mathrm{~m}^{3}$ & 3-13 days \\
\hline Mean & $51 \mathrm{~m}^{3}$ & $31 \mathrm{~m}^{3}$ & 7 \\
\hline
\end{tabular}


Table 4 continued

(H) Rye-grass

\begin{tabular}{lccc}
\hline \multicolumn{1}{c}{ Soil Texture } & $\begin{array}{c}\text { Gross Irrigation } \\
\text { Requirement }\end{array}$ & $\begin{array}{c}\text { Net Irrigation } \\
\text { Requirement }\end{array}$ & $\begin{array}{c}\text { Intervals } \\
\text { (Days) }\end{array}$ \\
\hline Sand & 25 & 15 & 2 \\
Loamy Sand & 35 & 21 & 2 \\
Sandy Loam & 50 & 30 & 3 \\
Loam & 70 & 42 & 4 \\
Sandy Clay Loam & 50 & 30 & 3 \\
Clay Loam & 70 & 42 & 4 \\
Silt & 120 & 72 & 7 \\
Silt Loam & 100 & 60 & 6 \\
Silt Clay Loam & 80 & 48 & 5 \\
Sandy Clay & 55 & 33 & 3 \\
Silty Clay & 70 & 42 & 4 \\
Clay & 60 & 36 & 4 \\
Clay Loam & 70 & 42 & 4 \\
Mode & 70 & 42 & 4 \\
Min-Max & $25-120$ & $15-72$ & $\mathbf{3 9}$ \\
\hline Mean & $\mathbf{6 6}$ & & $\mathbf{4}$ \\
\hline
\end{tabular}

(I) Sudan-grass

\begin{tabular}{lccc}
\hline \multicolumn{1}{c}{ Soil Texture } & $\begin{array}{c}\text { Gross Irrigation } \\
\text { Requirement }\end{array}$ & $\begin{array}{c}\text { Net Irrigation } \\
\text { Requirement }\end{array}$ & $\begin{array}{c}\text { Intervals } \\
\text { (Days) }\end{array}$ \\
\hline Sand & 27 & 16 & 3 \\
Loamy Sand & 37 & 22 & 4 \\
Sandy Loam & 53 & 32 & 6 \\
Loam & 75 & 45 & 8 \\
Sandy Clay Loam & 53 & 32 & 6 \\
Clay Loam & 75 & 45 & 8 \\
Silt & 128 & 77 & 14 \\
Silt Loam & 107 & 64 & 12 \\
Silt Clay Loam & 85 & 51 & 9 \\
Sandy Clay & 59 & 35 & 7 \\
Silty Clay & 75 & 45 & 8 \\
Clay & 64 & 38 & 7 \\
Clay Loam & 75 & 45 & 8 \\
Mode & 75 & 45 & 8 \\
Min-Max & $27-128 \mathrm{~m}^{3}$ & $16-77 \mathrm{~m}^{3}$ & $3-14$ days \\
\hline Mean & $\mathbf{7 0} \mathbf{~ m}^{\mathbf{3}}$ & $\mathbf{4 2} \mathbf{~ m}^{\mathbf{3}}$ & $\mathbf{8}$ \\
\hline
\end{tabular}

(J) Triticale

\begin{tabular}{|c|c|c|c|}
\hline Soil Texture & $\begin{array}{c}\text { Gross Irrigation } \\
\text { Requirement }\end{array}$ & $\begin{array}{c}\text { Net Irrigation } \\
\text { Requirement }\end{array}$ & $\begin{array}{c}\text { Intervals } \\
\text { (Days) }\end{array}$ \\
\hline Sand & 34 & 20 & 3 \\
\hline Loamy Sand & 47 & 28 & 5 \\
\hline Sandy Loam & 68 & 41 & 7 \\
\hline Loam & 95 & 57 & 9 \\
\hline Sandy Clay Loam & 68 & 41 & 7 \\
\hline Clay Loam & 95 & 57 & 9 \\
\hline Silt & 162 & 97 & 16 \\
\hline Silt Loam & 135 & 81 & 14 \\
\hline Silt Clay Loam & 108 & 65 & 11 \\
\hline Sandy Clay & 74 & 45 & 7 \\
\hline Silty Clay & 95 & 57 & 9 \\
\hline Clay & 81 & 49 & 8 \\
\hline Clay Loam & 95 & 57 & 9 \\
\hline Mode & 95 & 57 & 9 \\
\hline Min-Max & $34-162 \mathrm{~m}^{3}$ & $20-97 \mathrm{~m}^{3}$ & $3-16$ days \\
\hline Mean & $89 \mathrm{~m}^{3}$ & $53 \mathrm{~m}^{3}$ & 9 \\
\hline
\end{tabular}


Table 4 continued

\begin{tabular}{lccc}
\multicolumn{1}{c}{ Soil Texture } & $\begin{array}{c}\text { Gross Irrigation } \\
\text { Requirement }\end{array}$ & $\begin{array}{c}\text { Whet Irrigation } \\
\text { Requirement }\end{array}$ & $\begin{array}{c}\text { Intervals } \\
\text { (Days) }\end{array}$ \\
\hline Sand & 26 & 16 & 4 \\
Loamy Sand & 36 & 22 & 5 \\
Sandy Loam & 52 & 31 & 7 \\
Loam & 73 & 44 & 10 \\
Sandy Clay Loam & 52 & 31 & 7 \\
Clay Loam & 73 & 44 & 10 \\
Silt & 125 & 75 & 17 \\
Silt Loam & 104 & 62 & 14 \\
Silt Clay Loam & 83 & 50 & 12 \\
Sandy Clay & 57 & 34 & 8 \\
Silty Clay & 73 & 44 & 10 \\
Clay & 62 & 37 & 9 \\
Clay Loam & 73 & 44 & 10 \\
Mode & 73 & 44 & 10 \\
Min-Max & $26-125 \mathrm{~m}^{3}$ & $16-75 \mathrm{~m}^{3}$ & $4-17$ days \\
\hline Mean & $\mathbf{6 8 \mathbf { m } ^ { \mathbf { 3 } }}$ & $\mathbf{9 1}$ \\
\hline
\end{tabular}

Figure 4 shows the gross and net irrigation needs mean in $\mathrm{m}^{3}$ per 0.1 hectares for all field crops included in this study: alfalfa, barley, Egyptian clover, field (silage) corn, forage sorghum, lentil, oat, rye-grass, Sudan-grass, triticale, and wheat. Among crops, crops can be arranged descending with the gross and net irrigation requirements mean (alfalfa, triticale, forage sorghum, Sudan-grass, wheat, barley, rye-grass, field corn, oat, lentil, and Egyptian clover, respectively) as it is observed that there is a direct downward relationship with root depth Table 1. Thus, there is a strong positive correlation between gross irrigation requirements mean and root depth (Table 7).

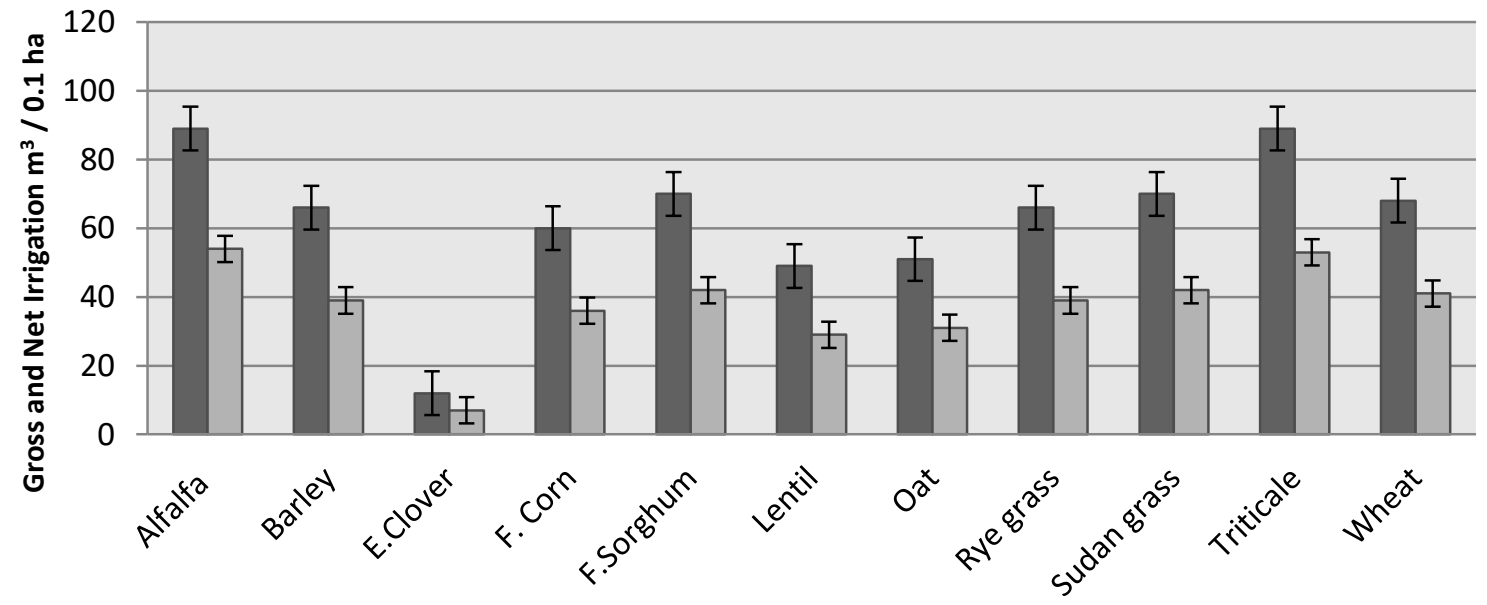

\section{$\square$ Mean GIR $\square$ Mean NIR}

Vertical bars indicate the $( \pm)$ standard error of the mean $(n=13)$

The effective root zone depth is the depth of soil used by the main body of the plant roots to obtain most of the stored moisture under proper irrigation. About $70 \%$ of the moisture extracted by the root is obtained in the top half of the root zone; about $20 \%$ from the third quarter; and about $10 \%$ from the soil in the deepest quarter of the root zone. Each plant has its root development characteristics. The application of irrigation water should be limited to an amount that will penetrate only to the effective root zone depth. Effective root zone or water extraction depth is the depth within which most crop roots are concentrated 
(Alberta Agriculture and Rural Development, 2011). Depths to which the roots of mature crops will deplete the available water supply when grown in a deep permeable, well-drained soil under average conditions (University of California UC Drought Management, cited in National Engineering Handbook, 2016).

Table 5 shows that the percent of decrease for net irrigation requirements mean concerning to the gross irrigation requirements mean equals (40.27) as a mean among eleven field crops. Field crops in this study and their root depths $(\mathrm{cm})$ were presented in the front of gross irrigation requirements mean $\left(\mathrm{m}^{3}\right)$ and the irrigation intervals mean (days) as it was derived by mathematical modelling (Table 6) to find the statistical correlation (Table 7).

The net irrigation outcome is a mathematical result of multiplying the gross irrigation value by the constant assumed factor of $60 \%$, which reflects the efficiency of surface irrigation, losses especially due to deep percolation and surface runoff, not losses due to evaporation. On the other hand, the formula of percent of the decrease in verbal reasoning is $(1-0.60$, which equals $40 \%$ ) (Table 5). This scientific observation should be considered as a necessity to shift towards drip irrigation where irrigation efficiency around $90 \%$ and a huge amount of water can be saved. There is also an imperative need to test varieties row spacing to schedule drip irrigation successfully.

Table 5. Percent of decrease for net irrigation requirements mean about the gross irrigation requirements mean for eleven field crops

\begin{tabular}{lccc}
\hline \multicolumn{1}{c}{ Crop } & $\begin{array}{c}\text { Mean } \\
\text { GIR }\end{array}$ & $\begin{array}{c}\text { Mean } \\
\text { NIR }\end{array}$ & $\begin{array}{c}\text { Percent of } \\
\text { Decrease }\end{array}$ \\
\hline Alfalfa & 89 & 54 & 0.39 \\
Barley & 66 & 39 & 0.41 \\
Egyptian Clover & 12 & 7 & 0.42 \\
Field (Silage) & 60 & 36 & 0.40 \\
Corn & & & \\
Forage Sorghum & 70 & 42 & 0.40 \\
Lentil & 49 & 29 & 0.41 \\
Oat & 51 & 31 & 0.39 \\
Rye-grass & 66 & 39 & 0.41 \\
Sudan-grass & 70 & 42 & 0.40 \\
Triticale & 89 & 53 & 0.40 \\
Wheat & 68 & 41 & 0.40 \\
\hline Mean & & & $\mathbf{0 . 4 0}$ \\
\hline
\end{tabular}

It is noted from Table 7 that the amount of the statistical correlation is $(0.82)$ between the root depth and irrigation intervals mean. But, it was (0.82) between irrigation intervals mean and the gross irrigation requirements mean. This means that the root depth is the main determinant factor of the gross requirements. Other studies and in-depth research should determine what is the main determinant factor for irrigation intervals such as soil texture, crop growth stage, and temperatures.
This study is only part of the integrated system of crop modelling in the case of crop rotation scheduling. Many studies have found similar results and emphasized the importance of crop rotations within agricul-tural development plans. A similar conclusion was recommended for forage agronomic crops in Jordan using treated wastewater (Massimi et al., 2018b).

It is also difficult to limit the specific soil texture of each crop unless other factors such as soil $\mathrm{pH}$ and the soil salinity limits may determine the recommended texture of each crop. This study needs to be scientifically proven on the research ground, with replicates to reduce the expected errors.

Table 6. Major and most common field crops grown in Jordan and their root depths $(\mathrm{cm})$ were presented in the front of gross irrigation requirements mean $\left(\mathrm{m}^{3}\right)$ and the irrigation intervals mean (days) as it was derived by mathematical modelling

\begin{tabular}{|c|c|c|c|c|}
\hline No. & Crop & $\begin{array}{c}\text { Root } \\
\text { Depth } \\
(\mathbf{c m})\end{array}$ & $\begin{array}{c}\text { Gross } \\
\text { Irrigation } \\
\text { Requirements } \\
\text { Mean } \\
\left(\mathbf{m}^{\mathbf{3}}\right)\end{array}$ & $\begin{array}{c}\text { Intervals } \\
\text { Mean } \\
\text { (Days) }\end{array}$ \\
\hline 1 & Alfalfa & 135.6 & 89 & 12 \\
\hline 2 & Barley & 99.6 & 66 & 9 \\
\hline 3 & $\begin{array}{l}\text { Egyptian } \\
\text { Clover }\end{array}$ & 17.78 & 12 & 1 \\
\hline 4 & $\begin{array}{l}\text { Field (Silage) } \\
\text { Corn }\end{array}$ & 91.44 & 60 & 4 \\
\hline 5 & $\begin{array}{l}\text { Forage } \\
\text { Sorghum }\end{array}$ & 106.68 & 70 & 8 \\
\hline 6 & Lentil & 73.7 & 49 & 6 \\
\hline 7 & Oat & 77.7 & 51 & 7 \\
\hline 8 & Rye-grass & 100 & 66 & 4 \\
\hline 9 & Sudan-grass & 106.68 & 70 & 8 \\
\hline 10 & Triticale & 135 & 89 & 9 \\
\hline 11 & Wheat & 103.8 & 68 & 9 \\
\hline
\end{tabular}

Table 7. Statistical correlation for eleven field crop root depths (cm), gross irrigation requirements mean $\left(\mathrm{m}^{3}\right)$, and irrigation intervals mean (days)

\begin{tabular}{lccc}
\hline & $\begin{array}{c}\text { Root } \\
\text { Depth }\end{array}$ & $\begin{array}{c}\text { GIR } \\
\text { Mean }\end{array}$ & $\begin{array}{c}\text { Intervals } \\
\text { Mean }\end{array}$ \\
\hline Root Depth & 1 & & \\
GIR Mean & 0.999 & 1 & \\
Intervals Mean & 0.82 & 0.82 & 1 \\
\hline
\end{tabular}

Figure 5 shows the regression statistics where the dependent factor (mean of irrigation intervals days) is significantly affected by the independent factor (root depth). The correlation value (0.82) is described as a high positive correlation. 
Figure 5. Regression of mean intervals and root depth, function, and $\mathbf{R}^{2}$

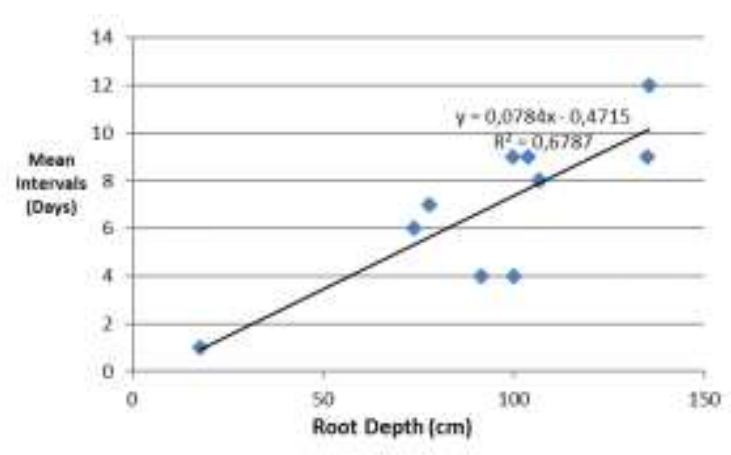

\section{CONCLUSION AND RECOMMENDATIONS}

It has been well recognized that the science of mathematics has succeeded to meet an academic irrigation scheduling in term of surface irrigation for field crops based on both soil hydrological and physical properties due to the presence of fully documented botanical, morphological, and ecological field crops description with guaranteed supportive logical, mathematical, and statistical modelling. Thus, the prevailing model of irrigation scheduling for field crops in Jordan remains a scientific (academic) one, where an extension scholar can depend on his model, other research scholars, and any other sources. Irrigation models using digital sensing is another alternative practical tool, it is designed based on mathematical fundamentals, and it considers soil hydrological and physical properties.
Extension scholar's decision to update the mathematical irrigation model depends on mutual advanced research findings. It is an act of choosing between simplifying the irrigation model based on (effective root depth, soil texture, critical growth stage, and temperature) or searching for renewable inputs (different varieties root depths, optimum row spacing of each crop, and drip irrigation mathematical modelling) or to take advantage of each merit in specific situations. The first method is the same as the author and his team's 2017 work on corn and sorghum plants within the Norman Borlaug Fellowship (Massimi et al., 2020). This underscores the need to value each merit of an irrigation model in specific situations before putting in place any type of procedure. In both cases, the input related to the effective root depth is a major and basic factor in mathematical irrigation scheduling.

It is, therefore, recommendable that extensionresearch based systems should focus on science to capacitate the complementary role of academics, research trials, and extension program demonstrations in rural development.

\section{ACKNOWLEDGEMENTS}

Thanks and gratitude to his Excellency Dr. Naem Mazahrih for the support, sponsorship, and respect of teamwork during the period of obtaining the Norman Borlaug Fellowship in the Florida Agricultural and Mechanical University (2017), especially his appreciation for integrating the skills of the researcher and extension scholar.

\section{REFERENCES}

Alberta Agriculture and Rural Development (ARD). (2011) Irrigation scheduling fact sheets. Cited in Alberta Irrigation Management Manual, 2016, Alberta, Canada.

Ali, M.H.-Hoque, M.R.-Hassan, A.A., Khair, A. (2007): Effects of deficit irrigation on yield, water productivity, and economic returns of wheat. Agricultural Water Management. 92: 151-161.

Anandhi, A. (2016): Growing degree days-ecosystem indicator for changing diurnal temperatures and their impact on corn growth stages in Kansas. Ecological Indicators. 61: 149-158.

Anandhi, A.-Blocksome, C.E. (2017): Developing adaptation strategies using an agroecosystem indicator: Variability in crop failure temperatures. Ecological Indicators. 76: 30-41.

Bonachela, S. (1996): Root growth of triticale and barley grown for grain or for forage-plus-grain in a Mediterranean climate. Plant and Soil. 183: 239-251.

Brouwer, C.-Heibloem, M. (1986): Crop Water Needs, Irrigation Water Management: Irrigation Water Needs, Food and Agricultural Organization, Rome.

Cakir, R. (2004): Effect of water stress at different development stages on vegetative and reproductive growth of corn. Field Crops Research. 89: 1-16.

Carlberg, C. (2014): Statistical analysis: Microsoft excel 2013. Que Publishing.
Dickinson, E.B.-Hyam, G.F.S.-Breytenbach, W.A.S.-Metcalf, W.D.-Bassoon, W.D.-Williams, F.R.-Scheepers, L.J.-Plint, A.P.-Smith, H.R.H.-Smith, P.J.-Van Vuuren, P.J.-Viljoen, J.H.-Archibald, K.P.-Els, J.N. (2004): Pasture handbook, Kejafa Knowledge Works, Maanhaarrand, South Africa.

Du, T.-Kang, S.-Sun, J.-Zhang, X.-Zhang, J. (2010): An improved water use efficiency of cereals under temporal and spatial deficit irrigation in north China. Agricultural Water Management. 97: 66-74.

Easton, Z.M.-Bock, E. (2016): Soil and Soil Water Relationships, Virginia Cooperative Extension, Virginia State University, USA, Petersburg.

Fan, J.-McConkey, B.-Wang, H.-Janzen, H. (2016): Root distribution by depth for temperate agricultural crops. Field Crops Research. 189: 86-74.

Greaves, G.E.-Wang, Y. (2017): The effect of water stress on radiation interception, radiation use efficiency and water use efficiency of maize in a tropical climate. Turkish Journal of Field Crops. 22: 114-125.

Info agro. (2018): Triticale Growing, Info Agro Exhibition, Spain. On-Line: [http://agriculture.infoagro.com/crops/triticalegrowing/]. 
Kahlon, M.S. (2017): Effect of planting methods and irrigation levels on water productivity of onion (Allium cepa L.). Indian Journal of Agricultural Research. 51: 510-513.

Kroeck, S. (2011): Crop Rotation and Cover Cropping: Soil Resiliency and Health on the Organic Farm (Organic Principles and Practices Handbook Series, a project of Northeast organic farming association) Kindle Edition. Chelsea Green Publishing, Vermont.

Massimi, M.-Al-Bdour, A. (2018a): A Short Scientific Note on the Horticultural Crops Optimum Planting Dates in Jordan. Egyptian Journal.of Horticulture. 45: 337-340.

Massimi，M.-Bader， N.-Khamish, K.H.-Al-S'uod，A. (2018b) Economic Analysis for Forage Agronomic Crops Grown Using Treated Wastewater in Kherbeh Als-Samra Region, Jordan. International Journal of Plant \& Soil Science. 22: 1-9.

Massimi, M.-Hasseb, M.-Legaspi, J. (2020). Growth Biometrics Response of Silage Corn and Forage Sorghum to Hybrid Vigor Under Multiple Irrigation Treatments. International Journal of Agricultural Science.5: 14-24.

Natural Resources Conservation Service (NRCS). (2014): Soil Bulk Density/Moisture/Aeration, Soil Quality Kit-Guides for Educators, United States Department of Agriculture USDA, USA.

Phocaides, A. (2007): Handbook on Pressurized Irrigation Techniques, Food and Agricultural Organization, Rome.

Randhawa, M.S.-Maqsood, M.-Shehzad, M.A.-Chattha, M.U.Chattha, M.B.-Nawaz, F.-Yasin, S.-Abbas, T.-Nawaz, M.M.Khan, R.D.-Zulfiqar, U. (2017): Light interception, radiation use efficiency and biomass accumulation response of maize to integrated nutrient management under drought stress conditions. Turkish Journal of Field Crops. 22: 134-142.
Reed, K.F.M. (2008): Berseem Clover, Pastures Australia, Factsheet, Australia.

Saraf, C.-Baitha, S. (1985): Water Use Patterns and Water Requirement of Lentil Planted on Different Dates. Lens News 12: 12-15. Cited in World Crops: Cool Season Food Legumes, Proceedings of the International Food Legume Research Conference on Pea, Lentil, Faba Bean, and Chickpea. Summerfield RJ. (Eds), 1986, Washington, USA.

Saxton, K.-Rawls, W. (2006): Soil Water Characteristic Estimates by Texture and Organic Matter for Hydrologic Solutions. Soil Science Society of America Journal. 70: 1569-1578.

Steynberg, R.E.-Nel, P.C.-Rethman, N.F.G. (1994): Soil Water Use and Rooting Depth of Italian Ryegrass (Lolium multiflorum Lam.) in a Small Plot Experiment. South African Journal of Plant and Soil. 11: 80-83.

Sustainable Agriculture Research \& Education (SARE). Berseem Clover. (2012): Managing Cover Crops Profitably, Handbook Series Book 9, Third Edition. Sustainable Agriculture Research \& Education SARE, National Institute of Food and Agriculture, United States Department of Agriculture USDA, USA.

University of California, UC Drought Management. Crop Rooting Depth. California, USA. On-Line: [http://ucmanagedrought.ucdavis.edu/Agriculture/Irrigation_Sc heduling/Evapotranspiration_Scheduling_ET/Frequency_of_Irr igation/Crop_Rooting_Depth/]. Source: in Part 623 National Engineering Handbook, Chapter 11, Sprinkler Irrigation, Natural Resources Conservation Service NRCS, 2016. United States Department of Agriculture USDA, USA 